Publisher: Faculty of Agronomy Čačak

\title{
Soil Quality and Proposal for Fertility Improvement of Arable Soil in Rasina District
}

\author{
Biljana Sikirić*, Vesna Mrvić, Olivera Stajković-Srbinović, Vladan Ugrenović, \\ Darko Jaramaz, Nikola Koković
}

Institute of Soil Science, Teodora Drajzera 7, 11000 Belgrade

*Corresponding author: biljana-s@sbb.rs, soils.sikiric@gmail.com

Received 5 November 2020; Accepted 19 March 2021

\begin{abstract}
A B S T R A C T
During the regular control of soil fertility in the Rasina District, it was established that the plots of land were distributed across Vertisol, Eutric Cambisol and Fluvisol types of soils, and to a lesser extent on Pseudogley and Ranker. The tested samples had different textures - sandy loam and loam, clay-sandy loam and clay loam, and clay. Plots of land that were of very acidic and acidic reactions were predominant, with medium amounts of humus, very low amounts of available phosphorus, and high amounts of available potassium. High or very high cation absorption capacity was found in about half of the examined fields; a deficient content of exchangeable Ca was recorded in $22 \%$ of plots and that of exchangeable $\mathrm{Mg}$ in $16 \%$ of plots, while an unfavorable $\mathrm{Ca} / \mathrm{Mg}$ ratio was measured in $44 \%$ of plots. The overall sensitivity to acidification was mainly moderate (50.6\% of plots) and strong (20.2\% of plots). Very high concentrations of mobile $\mathrm{Al}$, which could be toxic to plants, were found in 5 field plots.
\end{abstract}

Keywords: Rasina District, acid soils, acidification, macroelements, liming

\section{И 3 В О Д}

У Расинском округу током редовне контроле плодности земљишта, утврђено је да су парцеле распрострањене на земљишту типа вертисол, еутрични камбисол и флувисол, а мање на псеудоглеју и ранкеру. Земљиште је иловасте текстуре, повољних физичко-водних особина. Преовладавају парцеле јако киселе и киселе реакције, са средњим садржајем хумуса, јако ниским садржајем лакоприступачног фосфора и високим садржајем лакоприступачног калијума. У око половини испитиваних парцела установљен је висок или врло висок капацитет адсорпције катјона; у $22 \%$ парцела измерен је дефицитаран садржај изменљивог Са, а изменљивог $\mathrm{Mg}$ у 16\% парцела; неповољан однос Са/Мg измерен је у $44 \%$ парцела. Укупна осетљивост према ацидификацији (метода Holowaychuk и Fessenden, 1987) претежно је умерена (50,6\% парцела), а јака на 20,2\% парцела. Врло високе концентрације мобилног Al, које могу бити токсичне за биљке, нађене су на 5 парцела.

Кључне речи: Расински округ, кисела земљишта, ацидификација, макроелементи, калцизација.

\section{Introduction}

One of the most developed agricultural areas of Serbia is the Rasina District, located in the central part of Serbia. It encompasses the municipalities of Aleksandrovac, Brus, Varvarin, Kruševac, Trstenik, and Ćićevac, and occupies an area of $2667 \mathrm{~km}^{2}$. This research is primarily guided by the problem of acid and strongly acid arable soils, which are highly distributed in the Rasina District, as determined by previous examinations.

Acid and strongly acid soils are often limiting factors in plant production, as they hold an imbalance of biogenic elements and increase the solubility of heavy metals. Clark (1981) stated that soil acidity of $\mathrm{pH}$ 5.0 and below is a limiting growth factor for many plants due to toxic concentrations of $\mathrm{Al}, \mathrm{Fe}, \mathrm{Mn}$ and a possible deficiency of some biogenic elements such as $\mathrm{Ca}, \mathrm{Mg}, \mathrm{Zn}, \mathrm{B}$ and Mo.
However, the greatest problem comes from aluminum, which prevents normal root growth and root penetration to the deeper layers of soil. With more pronounced acidification, the concentration of mobile aluminum also rises, thus becoming toxic for plants when the levels reach the critical point (Haynes, 1984; Kinraide, 1991), while phosphorus, as one of the most important macronutrients, is fixed by $\mathrm{Al}$ and $\mathrm{Fe}$ into poorly soluble forms inaccessible to plants (Barber, 1995). On the other hand, the increased solubility of some microelements (e.g. $\mathrm{Zn}$ and $\mathrm{B}$ ) at low pH values could cause their rapid leaching from the root system zone, thus causing a lack of nutrients for plants. In conditions of increased concentrations of $\mathrm{H}^{+}$ions, harmful microelements are transformed into their readily available forms (Sauerbeck and Lubben, 1991).

Due to the weak fertility of acid soils, it is crucial to be familiar with their sensitivity to acidification processes, with the aim of using appropriate cultural practices promptly. 
The sensitivity of soil to acidification is conditioned primarily by the geological background, i.e. by the type and the extent of native substrate decomposition (Bergholm, 2003), as well as by the soil properties (soil solution reactions, base saturation, cation exchange capacity, soil texture, the content of organic matter), land use system (unreasonable use of acidic mineral fertilizers), and by the emissions of acidic substances from industrial plants (Misson et al., 2001). Acidification disrupts soil's buffering abilities (Feigenbaum et al., 1981; Tributh et al., 1987), primarily through the displacement and leaching of calcium and magnesium ions. Therefore, the rate of soil sensitivity to acidification is defined by the buffer capacity of the soil, i.e. its physical and chemical properties.

This research aims to comprehensively evaluate the state of soil fertility, as well as to make an assessment of soil acidification in the Rasina District, which would enable an adequate response in terms of sustainable recommendations for the application of soil cultural and improvement practices.

\section{Materials and methods}

The research was conducted on 110 representative surface samples, taken from the agricultural soil of cadastral parcels in the municipalities of the Rasina District (Aleksandrovac, Brus, Varvarin, Kruševac, Trstenik, and Ćićevac). Basic fertility parameters were determined from the average soil samples from the cadastral parcels of registered agricultural holdings. Soil $\mathrm{pH}$ was determined electrometrically in $\mathrm{H}_{2} \mathrm{O}$ and in $1 \mathrm{M} \mathrm{KCl}$. Humus was calculated from organic carbon (determined by a CNS Analyzer). Available P and K were determined by the AL-method of Enger-Riehm. Exchangeable $\mathrm{Ca}$ and $\mathrm{Mg}$ were extracted by ammonium acetate and determined by an ICP spectrometer (iCAP 6300 ICP-OES, Cambridge, UK). The level of $\mathrm{CaCO}_{3}$ was determined volumetrically using the Scheibler method. The composition of the soil adsorption complex was determined using the Kappen method. Mobile Al was determined by the Sokolov method and readings were recorded on the ICP. The mechanical composition of soil was determined by a combination of sieving and pipette methods.

Basic descriptive statistics and correlation methods were used for data processing. Visualization, management, creation, and analysis of data were performed in the GIS environment, using the ArcGIS program.

\section{Results and discussions}

\subsection{Pedological characteristics}

Several soil types are present in the Rasina District. Alluvial soil and somewhere humofluvisols were formed in the valleys of the rivers South (Južna) Morava, Great (Velika) Morava, West (Zapadna) Morava and its tributaries (Rasina and Pepeljušnica), and Toplica.

Miocene sediments (clays, sands, gravels) compose the surrounding lowland-hilly terrain, where vertisol, eutric cambisol, pseudogley, and luvisol were formed. The hilly-mountainous and mountainous relief includes the mountains Juhor, Gledićke Mountains, Veliki Jastrebac, Kopaonik, and Željin, where rankers were formed along with lithosols and regosols. On the flatter terrain, eutric and district cambisol are found on sandstones, flysch, shales, serpentine rocks, and granite.

The majority of the examined cadastral parcels belong to the vertisol soil type; followed by eutric cambisol and fluvisol, while pseudogley and rankers are less present (Map 1).

\subsection{Soil texture}

The tested samples have different textures - sandy loam and loam, clay-sandy loam and clay loam, and clay. In half of the samples, the soil has the texture of loam and sandy-clay loam, with very favorable properties.

Lighter mechanical composition, such as sandy loam, is present in samples on fluvisol and ranker. Heavier mechanical composition is found in vertisols, most commonly those in the region of Aleksandrovačka Župa, and in some samples of fluvisol, eutric cambisol and ranker developed on serpentine rock.

Some soils, such as luvisol and pseudogley, have a more favorable mechanical composition in the surface layer, but deeper layers have a higher clay content, which impedes root system growth, while, in pseudogley, it retains sub-surface water.

\subsection{Basic fertility parameters}

The data on $\mathrm{pH}$ in $1 \mathrm{M} \mathrm{KCl}$ showed that the examined soils of the selected land plots were in a high percentage of cases $(46.6 \%)$ very acidic $(\mathrm{pH}<4.5)$ and in $30.9 \%$ of cases acidic (pH 4.5-5.5), while weakly acidic (pH 5.5-6.5) and neutral (pH 6.5-7.2) soils made up only $25.5 \%$ of samples.

It is known that strongly acidic soils usually have less favorable physical and chemical properties, and microbiological activity. Pseudogleys, brownized vertisols, and rankers have a very acid reaction. On the other hand, fluvisols (known for their fertility) were mostly neutral (42.9\%), followed by weakly acid $(21.4 \%)$ and acid $(21.4 \%)$ samples, while only $14.3 \%$ of samples were strongly acid.

In terms of the humus content, it was medium $(1.5-4 \%)$ in $74.5 \%$ of examined plots; low $(<1.5 \%)$ in $6.4 \%$ of plots, and high $(>4 \%)$ in $19.1 \%$ of plots. The humus content of arable soils depends on land use and soil type; therefore especially high values of humus were measured on rankers and vertisols.

Very low contents of readily available $\mathrm{P}_{2} \mathrm{O}_{5}(<6 \mathrm{mg}$ $100 \mathrm{~g}^{-1}$ ) were measured on $40 \%$ of selected cadastral parcels; about $12 \%$ of cadastral parcels had low levels (6-10 mg 100 $\left.\mathrm{g}^{-1}\right), 10 \%$ medium levels $\left(10-16 \mathrm{mg} 100 \mathrm{~g}^{-}\right.$ 1 ), and $23.5 \%$ of parcels had a high and very high contents of this element (16-42 mg 100 $\mathrm{g}^{-1}$ ), (Table 1). Low amounts of readily available phosphorus are often found in pseudogley soils, where due to the strong acidic reaction phosphorus compounds bind into hardly soluble forms inaccessible to plants ( $\mathrm{Su}$ and Evans, 1996; Ma et al., 2001); this also occurs in vertisols, rankers, and cambisols. There is a moderately significant correlation $(r=0.553)$ between the content of readily available phosphorus and soil $\mathrm{pH}$. The interdependence of these parameters is weak due to the application of phosphorus fertilizers. 
Table 1.

Levels of readily available $\mathrm{P}$ and $\mathrm{K}$ in Soil

\begin{tabular}{cccc}
\hline $\begin{array}{c}\text { Level of } \\
\mathrm{P}_{2} \mathrm{O}_{5}\end{array}$ & $\begin{array}{c}\text { All } \\
\text { plots } \\
(\%)\end{array}$ & Level of $\mathrm{K}_{2} \mathrm{O}$ & $\begin{array}{c}\text { All plots } \\
(\%)\end{array}$ \\
\hline Very low & 40.0 & Very low & 0.0 \\
Low & 12.0 & Low & 7.0 \\
Medium & 10.0 & Medium & 32.0 \\
High & 14.5 & High & 40.0 \\
Very high & 9.0 & Very high & 21.0 \\
\hline
\end{tabular}

A low content of readily available $\mathrm{K}_{2} \mathrm{O}(<12 \mathrm{mg}$ $\left.100 \mathrm{~g}^{-1}\right)$ was found in approximately $7 \%$ of cadastral parcels, a medium content in $32 \%$, while high and very high contents were present in $61 \%$ of examined plots
(Table 1). Among the soil types, fluvisols and vertisols stood out for their high concentrations of potassium, with $79 \%$ of samples having high and $70 \%$ very high levels of this element. Fluvisols are known for their good fertility, while vertisols have a high content of clay, which contains potassium in its structure. Lower levels of potassium were measured in pseudogleys, which are characterized by low $\mathrm{pH}$ values, lower levels of base cations and reduced soil fertility. No correlation between $\mathrm{pH}$ value and readily available potassium content in soil was found, which was noted in other studies as well (Dugalić et al., 1995). It is known that the content of this element is, besides fertilization, significantly affected by the content and quality of clay.

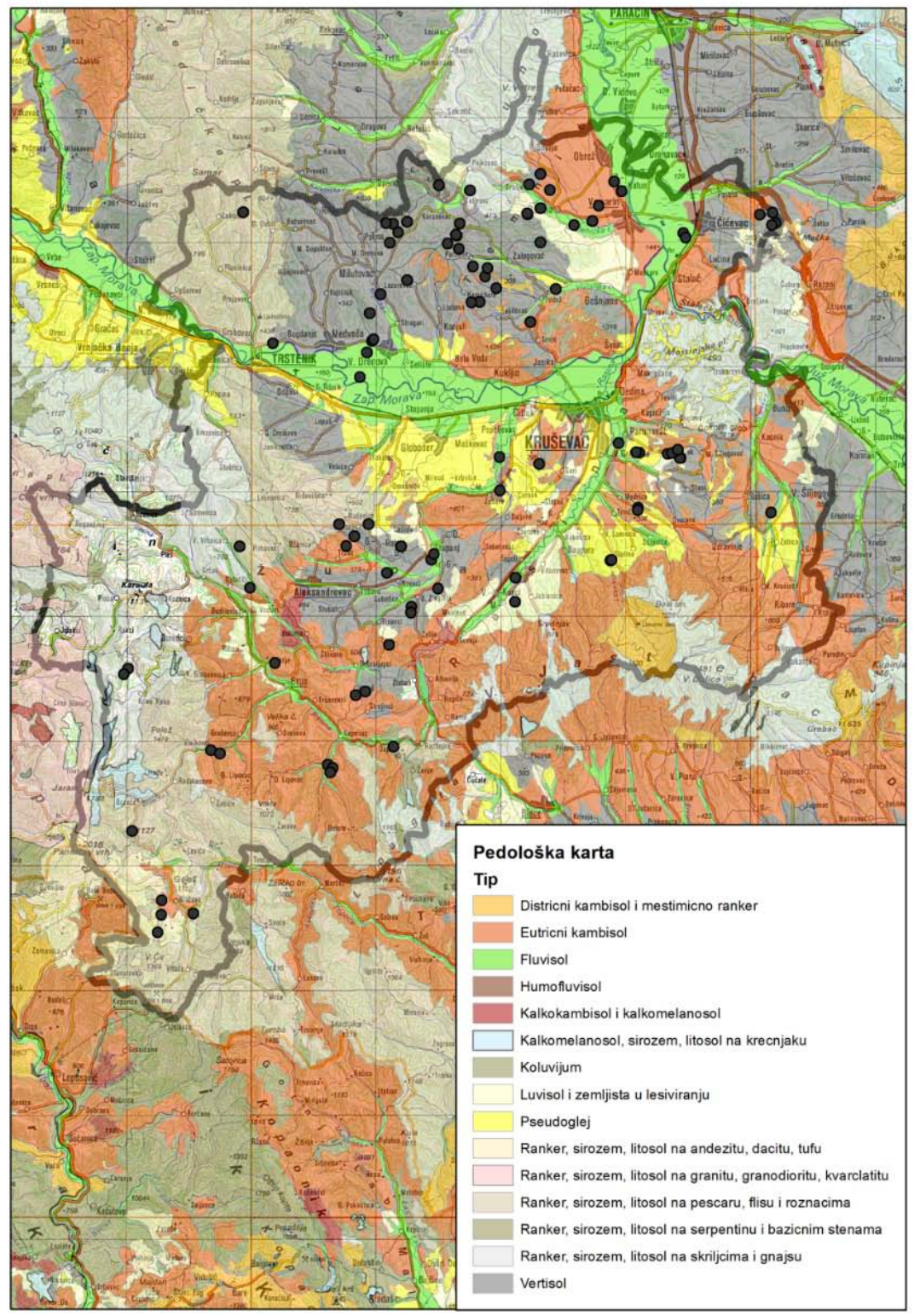

Map 1. Pedological Map of the Rasina District with the Locations of Examined Cadastral Parcels

\subsection{Composition of the adsorption complex}

The values of the total adsorption capacity of cations in the tested samples ranged from 15 to 52 cmol kg-1 (27 $\mathrm{cmol} \mathrm{kg}^{-1}$ on average). About half of the samples had a medium value (up to $25 \mathrm{cmol} \mathrm{kg}^{-1}$ ), while the rest of the samples had a high value $(25-35 \mathrm{cmol}$ $\left.\mathrm{kg}^{-1}\right)$, and less often a very high value $(6 \%$ of the samples). 
The values of hydrolytic acidity ranged from 0.8 meq $100 \mathrm{~g}^{-1}$ in base saturated soils to $24.4 \mathrm{meq} 100 \mathrm{~g}^{-1}$ in strongly acid soils rich in colloids. The average value of the tested plots was 8 meq $100 \mathrm{~g}^{-1}$.

Hydrolytic acidity values were used as the basis for the lime amount calculations required to neutralize acidity. According to the literature (Belić et al., 2014), liming is mandatory at $\mathrm{H}$ levels above 8 meq $100 \mathrm{~g}^{-1}$ and can be optionally carried out at levels $4-8$ meq $100 \mathrm{~g}^{-1}$ As the obtained rates are very high, partial soil neutralization is used, $25-50 \%$ of the calculated norm.

The total adsorption capacity consists not only of acidic cations, but also of base cations. The sum of adsorbed base cation (S) values depends on the type of geological substrate, soil reaction, and the amounts of clay and humus, but is also influenced by fertilization, liming, biological accumulation of bases, etc. The measured values of S vary from 4 to 49 meq $100 \mathrm{~g}^{-1}$.

The degree of adsorption complex base saturation (V) represents the percentage ratio of the sum of bases and the total adsorption capacity. Values range from $15-98 \%$ (average $68 \%$ ). About $19 \%$ of the samples were distric $(\mathrm{V}<50 \%)$, while the rest were eutric, and in carbonate soils the adsorption complex was saturated with bases.

\subsection{The contents of exchangeable calcium and magnesium}

In examined soils, the content of exchangeable $\mathrm{Ca}$

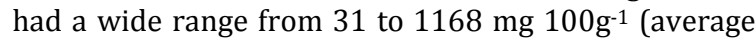
$243 \mathrm{mg} 100 \mathrm{~g}^{-1}$ ). The values were low (up to $100 \mathrm{mg}$ $100 \mathrm{~g}^{-1}$ ) in $22 \%$ of samples, in the range of $100-300 \mathrm{mg}$ $100 \mathrm{~g}^{-1}$ in $51 \%$ of samples, and above $300 \mathrm{mg}^{100 \mathrm{~g}^{-1} \text { in }}$ $27 \%$ of samples (Table 2). Lower levels were typical of acid soils, which dominate in this area. In addition, low contents also occurred in soils on serpentine rocks, or in soils formed on the material originating from these rocks.

The content of exchangeable $\mathrm{Mg}$ ranged from 5.6 to

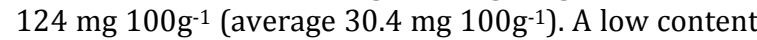

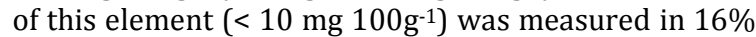
of the samples, which was mostly a consequence of the acidic soil reaction. The greatest number of samples, about $60 \%$, had concentrations in the range of $10-40$ mg $100 \mathrm{~g}^{-1}$, which is the average for soils in Serbia (Jakovljević et al., 2001), while in the remaining

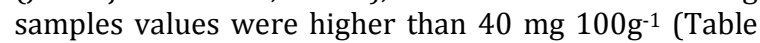
2). Vertisols had the highest concentrations of exchangeable Mg and were well supplied with it, due to the significant share of montmorillonite clay ( $43 \%$ of vertisol samples contained $10-40 \mathrm{mg} 100 \mathrm{~g}^{-1}$ and $35 \%$ had levels $>40 \mathrm{mg} 100 \mathrm{~g}^{-1}$ ). Rankers on serpentine rocks showed similar results.

The availability of $\mathrm{Mg}$ for plants depends on the molar ratio of $\mathrm{Ca}$ and $\mathrm{Mg}$, which is favorable for values from 1 to 5 . The Ca:Mg ratio < 5 was found in $56 \%$ of samples, while it was unfavorable in the rest of the samples. The ratio of 5-20 was present in $40 \%$ of the samples and the ratio $>20$ in $4 \%$, in which $\mathrm{Mg}$ deficiency could occur in the nutrition of plants sensitive to the lack of this element. In the examined samples, the average value of the $\mathrm{Ca}: \mathrm{Mg}$ ratio was 6.3 .

The correlation between the $\mathrm{pH}$ value and readily available Ca content was medium and significant $(\mathrm{r}=$ 0.697 ), while the correlation between $\mathrm{pH}$ and readily available $\mathrm{Mg}$ was weak and significant $(r=0.350)$.

\subsection{The content of mobile aluminum}

As found by Dugalić (1997), the concentrations of mobile Al greater than 6-10 mg $100 \mathrm{~g}^{-1}$ could have a detrimental effect on plants. With a decrease in $\mathrm{pH}$ value below 4.5, the content of mobile $\mathrm{Al}$ visibly increases. Foy (1988) reported that a decrease in acidity by only $0.1 \mathrm{pH}$ units can double the concentration of mobile aluminum in the root system zone. The concentrations of mobile $\mathrm{Al}$ in the samples ranged from $0-20 \mathrm{mg} 100 \mathrm{~g}^{-1}$. In most samples (80\%), the concentrations of this element were less than 10 mg $100 \mathrm{~g}^{-1}$ and in about $2 / 3$ of the cases, no presence of aluminum was detected or the measured concentration was $<1 \mathrm{mg} 100 \mathrm{~g}^{-1}$. Due to the strongly acidic soil reaction, in five locations $\mathrm{Al}$ concentrations were 10 $20 \mathrm{mg} 100 \mathrm{~g}^{-1}$, which could be potentially harmful to plants, depending on cultivated species. The results showed a significant negative correlation between the $\mathrm{pH}$ value and mobile $\mathrm{Al}$ concentrations in the soil $(\mathrm{R}=$ 0.601 ). These findings are in agreement with previous publications. Sikirić et al. (2009) showed a high negative correlation between these two parameters ( $R$ $=-0.795)$.

Table 2.

Levels of Exchangeable Calcium and Magnesium in Soil

\begin{tabular}{cccc}
\hline $\begin{array}{c}\text { Levels of readily } \\
\text { available Ca }\end{array}$ & $\begin{array}{c}\text { All plots } \\
(\%)\end{array}$ & $\begin{array}{c}\text { Levels of readily } \\
\text { available Mg }\end{array}$ & $\begin{array}{c}\text { All plots } \\
(\%)\end{array}$ \\
\hline Deficient & 22 & Deficient & 16 \\
Medium & 51 & Medium & 60 \\
High & 27 & High & 24 \\
\hline
\end{tabular}

Table 3.

Categories of Soil Sensitivity to Acidification (Holowaychuk \& Fessenden Methods, 1987)

\begin{tabular}{ccccc}
\hline Sensitivity level & $\begin{array}{c}\text { Sensitivity to base } \\
\text { loss } \\
(\%)\end{array}$ & $\begin{array}{c}\text { Sensitivity to } \\
\text { acidification } \\
(\%)\end{array}$ & $\begin{array}{c}\text { Sensitivity to } \\
\text { aluminum } \\
\text { solubilization } \\
(\%)\end{array}$ & $\begin{array}{c}\text { Total sensitivity to } \\
\text { acidification } \\
(\%)\end{array}$ \\
\hline Strong & 20 & 6 & 34 & 20 \\
Moderate & 52 & 7 & 26 & 51 \\
Weak & 28 & 49 & 29 & 29 \\
Moderate tu weak & 0 & 27 & 11 & 20 \\
\hline
\end{tabular}

\subsection{Soil sensitivity to acidification}

Soil sensitivity to acidification was determined using the Holowaychuk \& Fessenden method (1987), which defines cation exchange capacity (CEC) and water $\mathrm{pH}$ values as key soil properties. The total measured sensitivity to acidification was based on three categories of sensitivity - sensitivity to base loss, 
sensitivity to acidification, and sensitivity to aluminum solubilization (Table 3).

Sensitivity to base loss refers to soil susceptibility to leaching of base cations (primarily $\mathrm{Ca}^{2+}, \mathrm{Mg}^{2+}$ and $\mathrm{K}^{+}$) with $\mathrm{H}^{+}$ions. The decrease in the concentration of base cations ( $\mathrm{Ca}, \mathrm{Mg}, \mathrm{K})$ and microelements $(\mathrm{B}, \mathrm{Zn}, \mathrm{Mo}$ ) is influenced by the increase in soil acidity. Most of the samples (52\%) had medium sensitivity, while $28 \%$ of samples showed low sensitivity to base loss. Special attention should be paid to the samples (land plots) in which strong sensitivity to base loss was measured (20\%).

Sensitivity to acidification in the Rasina District is not particularly pronounced. The categories of weak and moderately weak acidification prevail. Moderate acidification was found in $7 \%$ of the samples and high acidification in $6 \%$ of the samples.

Sensitivity to aluminum solubilization is a very important parameter in determining the overall sensitivity to acidification. According to Huang (1988), if the $\mathrm{pH}$ is below 4, the monomeric $\mathrm{Al}^{3+}$ form will dominate, and this form is the most harmful for plants.

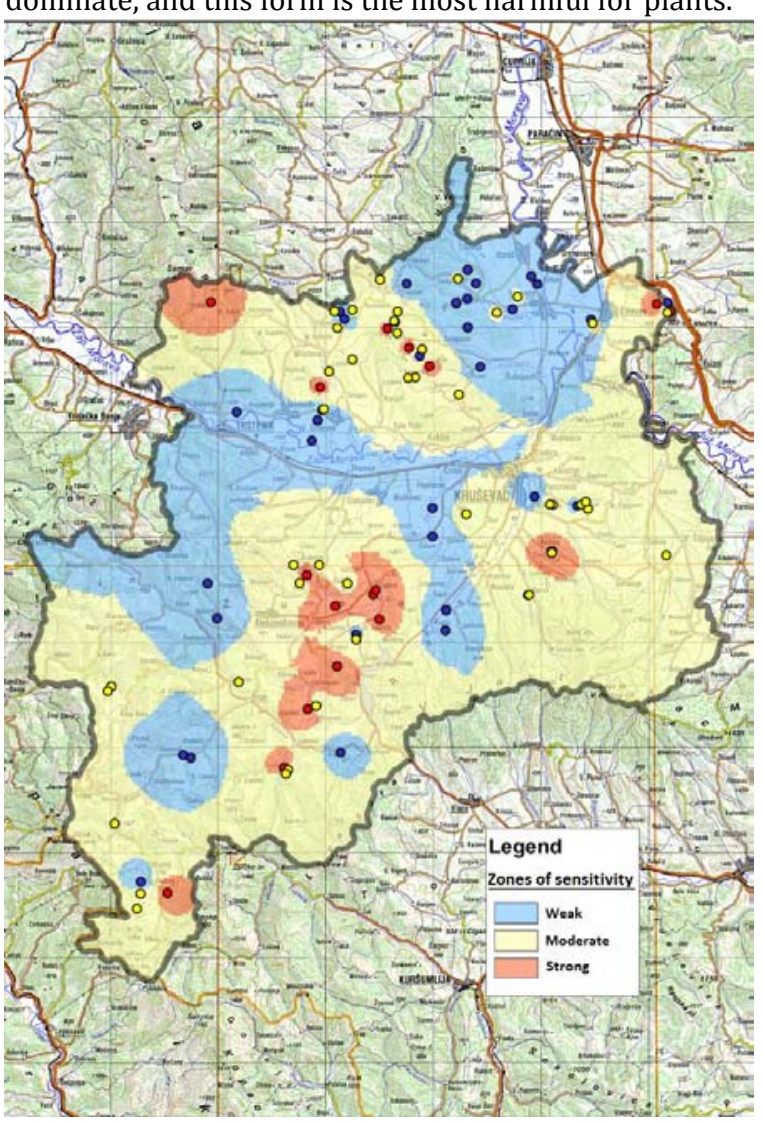

Map 2. Total Soil Sensitivity to Acidification

(Holowaychuk and Fessenden Methods, 1987)

A significant number of samples (about 34\%) showed strong sensitivity to Al solubilization. Other samples were moderately sensitive (26\%), weakly sensitive $(29 \%)$, or moderately to weakly sensitive $(11 \%)$ to $\mathrm{Al}$.

Mrvić et al. (2012) reported that, during acidification, the content of mobile $\mathrm{Al}$, especially its monomeric form, in the soil solution had a less damaging effect on plants if the soils had favorable characteristics regarding $\mathrm{pH}, \mathrm{CEC}$ and $\mathrm{BS}$.

The overall sensitivity to acidification (Holowaychuk and Fessenden, 1987) on the tested plots of the Rasina District was mostly moderate (51\%) and weak (29\%), while it was strong in $20 \%$ of the samples (Map 2). According to the data obtained, it is clear that the sensitivity to base loss had the greatest influence on the overall sensitivity to acidification, since the share by sensitivity category was almost identical for both parameters. In addition, the study found a significant relationship between the $\mathrm{pH}$ value and the total sensitivity; strongly acid and acid soils made up $74.5 \%$ of the samples, while moderate and strong sensitivity were found in $71 \%$ of the samples.

Zones of strong sensitivity occur in some regions with rankers on sandstones, brownized vertisols and ilimerized eutric cambisols.

\section{Conclusions}

In the Rasina district, the high share of acidic soils is a significant limitation to intensive agricultural production, which can be significantly reduced by melioration measures liming and input of adequate amounts of organic matter). By defining the degree of soil sensitivity to acidification it is possible to take timely measures in regard to reducing the general acidity of the soil. It is advised to apply small doses of lime on several occasions alongside organic fertilizers, which are sources of necessary microelements. During regular fertilization, mineral fertilizers containing Ca (KAN) should be applied as well. In samples with low and very low concentrations of available phosphorus, it is recommended to use NPK mineral fertilizers rich in phosphorus or MAP $\left(52 \% \mathrm{P}_{2} \mathrm{O}_{5}\right)$. Soil fertility control at the plot level enables balanced application of fertilizers, which, along with appropriate cultural practices and proper crop selection, contributes to preserving soil fertility and to the better use of the soil's potential.

\section{Acknowledgment}

This work was supported by the Ministry of Education, Science and Technological Development of the Republic of Serbia (Contract No. 451-03-9/202114/200011) and Ministry of Agriculture, Forestry and Water Management of the Republic of Serbia.

\section{Declaration of competing interest}

The authors have no conflicts of interest to declare.

\section{References}

Barber, S.A. (1995). Soil Nutrient Bioavailability. A mechanistic approach. Wiley, New York.

Belić, M., Nešić, Lj., Ćirić, V. (2014). Practicum in pedology. University of Novi Sad, Faculty of Agriculture, Novi Sad (in Serbian with English abstract).

Bergholm, J., Berggren, D. and Alavi, G. (2003): Soil acidification induced by ammonium sulphate addition in a Norway spruce forest in southwest Sweden. Water, Air and Soil Pollution, 148, 87-109.

Clark, R.B. (1981): Mineral Nutritional Factors Reducing Sorghum Yields: Micronutrients and Acidity. Proceedings of the International Symposium on Sorghum, Patancheru, A. P., India, 179-188.

Dugalić, G., Vesković, M., Jovanović, Ž. (1995). Uticaj primene kreča, organskih i mineralnih đubriva na agrohemijske promene pseudogleja i prinos kukuruza. Savetovanje "Popravka kiselih zemljišta Srbije primenom krečnog đubriva Njival Ca“, Zbornik radova, Paraćin, 126-137. 
Dugalić, G. (1997). Karakteristike Kraljevačkog pseudogleja i iznalaženje mogućnosti za povećanje njegove produktivne sposobnosti. Doktorska disertacija. Poljoprivredni fakultet, Univerzitet u Beogradu.

Feigenbaum, S., Edelstein, R.E., Shainberg, J. (1981). Release rate of potassium and structural cations from mica to ion exchangers in dilute solutions. Soil Science Society of America Journal, 45, 501-506.

Foy, C.D. (1988). Plant adaptation to acid, aluminium toxic soils. Communications in Soil Science and Plant Analysis, 19, 959-987.

Haynes, R.J. (1984). Effect of lime, silicate, and phosphate application on the concentrations of extractable aluminium and phosphate in a spodosol. Soil Science, 138, 8-14.

Holowaychuk, N, Fessenden, R J. (1987). Soil sensitivity to acid deposition and the potential of soils and geology in Alberta to reduce the acidity of acidic inputs. Canada: $\mathrm{N}$. P. Web.

Huang, P.M. (1988). Ionic Factors Affecting Aluminium Transformations and the Impact on Soil and Environmental Sciences. Advances in Soil Science, 8, 60.

Jakovljević, M., Kostić, N., Antić-Mladenović, S. (2001). Supply of important types of soil in Serbia with basic alkaline elements $(\mathrm{Ca}, \mathrm{Mg}, \mathrm{K}$ and $\mathrm{Na}$ ). Proceedings of the $\mathrm{X}$ Congress of JDPZ, Vrnjačka Banja, CD Procceding (in Serbian with English abstract).

Kinraide, T.B. (1991). Identity of the rhizotoxic aluminium species. Plant and Soil, 134, 167-178.
Ma, J.F.., Ryan, P.R., Delhaize, E. (2001). Aluminium tolerance in plants and the complexing role of organic acids. Trends in Plant Science, 6, 273-278.

Misson, L., Ponette, Q., André, F. (2001). Regional scale effects of base cation fertilization on Norway spruce and European beech stands situated on acid brown soils: soil and foliar chemistry. Annales of Forest Science, 58, 699712.

Mrvić, V., Čakmak, D., Sikirić, B. Nikoloski, M., Delić, D. Belanović, S., Beloica, J. (2012). Uticaj zakišeljavanja na sadržaj vodorastvornog aluminijuma u pseudoglejevima. Ratarstvo i povrtarstvo, 49(3), 257-262.

Sauerbeck, D., Lubben, S. (1991). Effects of municipal disposals on soils, soil organisms and plants. In: Berichte aus der okologichen Forschung. Vol. 6. Edited by Forschungszentrum Julich, Julich: Zentralbibliotek, 1-32.

Sikirić, B. Mrvić, V., Stevanović, D., Maksimović, S, Stajković, O., Bogdanović D. (2009).The Effects of Calcification, Urea and Al Salts on Fe, Mn and Al Contents in the Soil and Raspberry Leaves. Agrochimica, 53, N.4

Su, C. and Ewans, Lj. (1996): Soil solution chemistry and alfalfa response to $\mathrm{CaCO}_{3}$ and $\mathrm{MgCO}_{3}$ on an acid Gleysol. Canadian Journal of Soil Science, 796, 41-47.

Tributh, H., Boguslawski, V.E., Liers, V.A., Steffens, S. And Mengel, K. (1987): Effect of potassium removal by crops on transformation of illitic clay minerals. Soil Science, 143, 404-409. 